\title{
Therapeutic applications of ghrelin agonists in the treatment of gastroparesis
}

\author{
Andrea Shin, M.D., M.S. \\ John M. Wo, M.D. \\ Division of Gastroenterology and Hepatology \\ Indiana University School of Medicine \\ Indianapolis, IN
}

Word Count: 2989

Key Words: ghrelin, gastroparesis, motilin, gastric emptying, diabetes, orexigenic hormone, growth hormone, vagus, TZP-101, TZP 102, ulimorelin, RM-131

\author{
Correspondence: \\ John M. Wo, MD \\ Professor of Medicine \\ Indiana University School of Medicine \\ Division of Gastroenterology and Hepatology \\ Rm 1634, Indiana University Hospital \\ 550 University Blvd \\ Indianapolis, IN 46202 \\ Phone: (317) 948-45272 \\ Fax: (317) 948-0164 \\ Email: jmwo@iu.edu
}

This is the author's manuscript of the article published in final edited form as:

Shin, A., \& Wo, J. M. (2015). Therapeutic Applications of Ghrelin Agonists in the Treatment of Gastroparesis. Current Gastroenterology Reports, 17(2), 1-9. http://doi.org/10.1007/s11894-015-0430-8 


\begin{abstract}
There remains an unmet need for effective pharmacologic treatments for gastroparesis. Ghrelin is the endogenous ligand for the growth hormone secretagogue receptor and has been shown to regulate energy homeostasis and exert prokinetic effects on gastrointestinal motility. In recent years, several ghrelin receptor agonists have been studied in clinical trials of patients with diabetic gastroparesis. The intravenous macrocyclic peptidomimetic, TZP-101 initially suggested improvement in gastroparesis symptoms with intravenous administration when compared to placebo. However, in subsequent studies of oral preparations, TZP-102 failed to confirm these results. Another ghrelin receptor agonist, RM-131 was recently shown to significantly accelerate gastric emptying (GE) in patients with type 1 and type 2 diabetes and delayed GE. RM-131 reduced total Gastroparesis Cardinal Symptom Index-Daily Diary (GCSI-DD) and composite scores among type 1 diabetics. Continued development of ghrelin agonists should be explored in attempts to expand therapeutic options for the treatment of gastroparesis.
\end{abstract}




\section{Introduction}

Gastroparesis is a disorder of gastric motility characterized by a constellation of cardinal upper gastrointestinal (GI) symptoms including nausea, vomiting, early satiety or postprandial fullness, bloating, and abdominal pain that occurs in association with delayed gastric emptying (GE) without mechanical obstruction of the stomach [1]. It is a heterogeneous disorder in which different etiologies may impact symptoms or response to treatment. The most common etiologies of gastroparesis include diabetes and postsurgical, followed by neurologic, rheumatologic and other miscellaneous disorders [2]. However, the etiology is unknown in approximately 40\% of patients with gastroparesis, a condition identified by idiopathic gastroparesis. Mechanisms that contribute to pathophysiology of gastroparesis are variable, and gastric emptying profiles cannot specifically distinguish neuropathic from myopathic gastroparesis [3]. Other factors that have been implicated in pathogenesis include impaired glycemic control [4], abnormalities of interstitial cells of Cajal (ICCs) [5,6], alterations in immune infiltrate marked by increase in CD45 and CD68 immunoreactivity [5], decreased heme oxygenase-1 [7,8], and loss of neuronal nitric oxide synthase (nNOS) [5,7,9,10].

The clinical impact of gastroparesis is significant; symptoms, particularly pain, are associated with impaired quality of life and increased anxiety or depression [11] while examination of national trends has shown a $>200 \%$ increase in overall hospitalizations for gastroparesis [12]. There remains a need for development of effective and targeted pharmacologic treatments. 
Prokinetic agents should be considered in the pharmacologic treatment of gastroparesis to improve gastric emptying and symptoms of gastroparesis [13]. Currently, the only FDAapproved prokinetic agent in the U.S. remains metoclopramide [14], a potent central and peripheral dopamine receptor antagonist that exerts its effects through suppression of the central vomiting center and stimulation of gastric motility via receptor-mediated actions resulting in increased gastric tone, intragastric pressure, antroduodenal coordination and accelerated gastric emptying $[15,16]$. However, it's use is limited to short-term treatment (no greater than 12 weeks) due to CNS side-effects such as anxiety, agitation, abnormal movements, dystonic reactions, somnolence or confusion, and intractable tardive dyskinesia [17,18]. Other agents include domperidone, which is not available in the U.S. but has been made available through a special program by the FDA [13]. Eryrthromycin, a motilin receptor, may also be utilized but tachyphylaxis remains a limiting factor in its long-term use [17]. More recently, the 28 amino acid residue peptide, ghrelin, has been identified as a potential treatment for impaired gastric emptying due to its actions on intestinal motility and food intake (reviewed in references 19 and 20).

\section{The role of Ghrelin}

Originally identified in 1999 as the natural ligand for the growth hormone secretagogue receptor (GHS-1a) or ghrelin receptor (GRLN-R) [19,20], ghrelin is an orexigenic hormone produced mainly in the oxyntic mucosa of the stomach [22] with significant sequence similarity to motilin [23]. It is derived from the human ghrelin gene via alternative splicing [24] and synthesized from precursor peptides that undergo post-translational processing [25]. The majority of circulating ghrelin occurs in the form of deacyl ghrelin which lacks an octanoyl 
group that is required for the hormone to be biologically active [26]. Octynoylation at serine-3 of ghrelin is mediated by O-acyltransferase (GOAT), a polytopic membrane-bound enzyme [27] and activation of GRLN-R by biologically active ghrelin results in direct stimulation of pituitary growth hormone (GH) release. Both ghrelin and GRLN-R (a G-protein-coupled receptor) are widely expressed throughout human tissue $[19,28]$. Thus, in addition to control of GH secretion, ghrelin serves to regulate diverse digestive processes [22], energy homeostasis and food intake [29,30], and numerous other systems (reviewed in 19, 28) including the immune system [31]], reproductive system [32], cardiovascular system [3334], adrenal glands, neoplastic proliferation, and osteoblastic function [35].

Regulation of energy homeostasis by ghrelin has made ghrelin an appealing target for treatment of metabolic disorders including obesity and type 2 diabetes. Ghrelin influences fat deposition [36], induces food intake through peripheral and central mechanisms [37] and appears to be involved in the rewarding properties of food intake through enhancement of hedonic and incentive responses to food-related cues [38]. Fasting expression of ghrelin has been shown to be increased by a high fat diet in a mouse model [39] and in patients with anorexia nervosa and cachexia, plasma ghrelin levels are increased while lower plasma ghrelin levels are observed in obese individuals compared to lean persons or controls [40,41]. Clinical trials in humans conducted with ghrelin in cachexia associated with cancer, cardiac and chronic lung disease have also shown increases in appetite, weight and cardiac output without significant toxicity [42-44].

\section{Effects of ghrelin on gastrointestinal motility}


Effects of ghrelin on upper GI functions appear to be mediated through vagal signaling, direct stimulation of the enteric nervous system or via direct effects on the CNS after crossing of the blood-brain barrier [19]. In vitro studies have demonstrated presence of GRLN-R in enteric nervous system of human and animal intestinal preparations [45,46]. Enhanced electrical field stimulation (EFS)-induced contractions and a dose-dependent enhancement of the aftercontraction evoked during EFS have been observed with administration of ghrelin to rodent stomach strips $[45,47,48]$ via effects that appear to be mediated via cholinergic and tachynergic pathways $[47,49,50]$. Prokinetic effects of ghrelin on GI transit in vivo in rodents have been demonstrated with various routes of administration [reviewed in reference 19] in post-surgical, opioid-induced, and diabetic models. Administration of acylated ghrelin or ghrelin potentiators improved the delayed GE and decreased antral motility in mice exposed to restraint stress [51].

The role of ghrelin on the migratory motor complex (MMC) has also been studied in several animal models to show stimulation of phase II of the MMC via the vagus nerve in the house musk shrew, Suncus murinus [52] and induction of a fasted motor pattern, enhancing motility of the antrum and duodenum in the fed or fasted state of healthy rodents [53-56]. Administration of ghrelin and the endogenous acyl-ghrelin potentiator, rikkunshito, restored fedlike motor activities to fasted activities in fenfluramine-treated rats and in a cancer anorexiacachexia animal model [57]. Meanwhile, consistent reports of effects of ghrelin on colonic contractility have been lacking despite tissue expression of GRLN-R [58-62]. Animal studies in dogs and rodents have shown no effect on colonic motility with intravenous administration of ghrelin, while central or intraperitoneal administration has demonstrated stimulation of colonic motility reflected by decreased colonic transit time and increased intracolorectal pressures and 
fluid output [63-67], suggesting that effects of ghrelin or ghrelin agonists on colonic motility are centrally mediated, requiring crossing of the blood brain barrier.

Studies in healthy human volunteers have shown induction of a premature phase III (MMC) using a pharmacologic dose of ghrelin [68] and inhibition of gastric accommodation when ghrelin was administered at higher doses was observed by Ang et al., but this was not associated with an increase in upper GI symptoms or satiety [69]. Cremonini et al. showed no effect on GE of solids or gastric accommodation by single photon emission CT (SPECT) using an intravenous bolus synthetic human ghrelin $(0.33 \mu \mathrm{g} / \mathrm{kg})$ that stimulated GH within the physiologic range of humans [71]. Meanwhile dosing administration of ghrelin with an infusion rate of $10 \mathrm{pmol} / \mathrm{kg} \cdot \min$ demonstrated acceleration in GE in normal humans in a separate study by Levin et al [72].

\section{Current clinical trials of ghrelin agonists in gastroparesis}

Due to its role in modulation of energy homeostasis and GI motility, ghrelin has been identified as a potential treatment for gastroparesis. Abnormal responses to sham feeding with impaired increases in systemic ghrelin have been observed in patients with diabetic and postsurgical gastroparesis when compared to idiopathic gastroparesis and normal controls [72], suggesting that alterations in ghrelin may play a role in gastroparesis. In a randomized, doubleblind, cross-over study, administration of a ghrelin infusion increased GE of a 330 kcal ricepudding test meal in seven of ten patients with diabetic gastroparesis and this effect was independent of vagal tone [73]. Similar results have been found in a study of six patients with idiopathic gastroparesis with enhanced GE and decreased meal-related symptom scores [74] as 
well as patients with neurogenic gastroparesis using bolus doses of 1 or $4 \mu \mathrm{g} / \mathrm{kg}$ of ghrelin to suggest extravagal prokinetic actions of ghrelin [75].

Although the potential for ghrelin as a prokinetic agent in the treatment of GI motility disorders such as gastroparesis is promising, it is limited by its short half-life [76] and plasma instability. Consequently, several synthetic ghrelin agonists have been developed and investigated for clinical use. TZP-101 (ulimorelin) is a first-in-class macrocyclic ghrelin analogue with potent binding affinity for the ghrelin receptor [77]. Initial investigations of this agent in patients with diabetic gastroparesis were promising with 20\% reduction in GE half-time of solids vs. placebo in a proof of concept study with a trend towards decreased overall postprandial symptoms and postprandial fullness (Table 1) [78]. A phase 2 multicenter doseranging study in patients with moderate to severe symptomatic diabetic gastroparesis subsequently demonstrated significant improvements from baseline on day 4 in Gastroparesis Cardinal Symptom Index (GCSI) loss of appetite and vomiting scores with the $80 \mu \mathrm{g} / \mathrm{kg}$ TZP101 dose when compared to placebo and a 25\% improvement in GE half-time for a small subset of combined TZP-101 dose groups compared to a 8\% improvement with placebo, although differences in GE $T_{1 / 2}$ were not statistically significant (Table 1) [79]. Post-hoc analysis of a subset of patients with severe nausea and vomiting (baseline severity score of $\geq 3.5$ on the GCSI Nausea/Vomiting subscale) enrolled in this phase 2 study found that nausea and vomiting at the end of treatment (day 4) were significantly reduced for the $80 \mu \mathrm{g} / \mathrm{kg}$ TZP-101 dose compared to placebo and at 30 day follow-up, the improvement of nausea and vomiting appeared to persist for the $80 \mu \mathrm{g} / \mathrm{kg}$ and all TZP-101 dose groups (figure 1), although findings did not reach statistical significance (Table 1) [80]. No significant safety issues were identified in either the multicenter 
study or subset population, demonstrating TZP-101to be safe and well tolerated with a relatively benign side effect profile [78-80].

Following TZP-101, oral TZP-102 was developed as a unique synthetic ghrelin receptor agonist with a prolonged half-life and promotility activity demonstrated in a rat model of GE with dose-dependent increases in GE of up to 51\% compared to vehicle. In a phase 2a clinical study, 92 patients with diabetic gastroparesis were randomized to once-daily TZP-102 (10, 20, $40 \mathrm{mg}$ ) or placebo. Significant diabetic gastroparesis symptom improvements were observed in the GCSI for all TZP-102 doses compared to placebo. In contrast, no significant improvements were observed in GE $T_{1 / 2}$, the primary efficacy endpoint, with any dose (Table 1) [81]. Two phase 2b double-blind, randomized, placebo-controlled clinical trials (studies TZP-102-CL-G003 and TZP-102-CL-G004) were subsequently conducted to evaluate 12 weeks of once daily and three times daily administration of oral TZP-102 in patients with diabetic gastroparesis with the primary outcome measure being average change from baseline through end-of treatment in Daily Diary of Gastroparesis Symptoms Questionnaire (GSDD). Prior results could not be confirmed in these investigations, as improvement in the GSDD were observed in all treatment arms, with no significant difference between intervention and placebo. GE analysis showed no significant differences in change-from-baseline in Week 12 with treatment or placebo (Table 1). Study TZP102-CL-G004 was prematurely stopped due to lack of efficacy in patients with diabetic gastroparesis [82].

Several explanations for the observed lack of efficacy and conflicting results between the phase 2a and $2 \mathrm{~b}$ studies have been proposed: (a) a larger than anticipated placebo-response that was more than double that originally anticipated, (b) variations in study design including 
differences in breath test methods (6h 13C-octanoate testing in the phase 2a study and 3h 3CSpirulina platensis testing in the phase $2 \mathrm{~b}$ study) and diabetes type between the two studies, (c) presence of confounding by use of concomitant medications by study participants, (d) a 4-week vs. 12-week study duration with lack of durability assessment in the phase 2a study [82,83]. Nevertheless, the bottom line that neither study showed efficacy with regards to the primary study endpoint remains the same and in conclusion, therapeutic benefits of treatment of TZP-102 could not be demonstrated.

RM-131 is a novel pentapeptide ghrelin receptor agonist with 100-fold more potency than human ghrelin in reversing gastric ileus in animal [84]. In pre-clinical studies prior to acquisition of RM-131 by Rhythm Pharmaceuticals, RM-131 has been shown to cause a dose-dependent increase in food intake and weight gain (both fat and lean mass) with greater potency than human ghrelin [85]. In a rat models, RM-131 was successful in reversing postsurgical, opiate-induced gastric ileus while in normal, nonsurgical primates, RM-131 increased the GE rate [86]. RM-131 also displayed anti-inflammatory effects and increased survival in models of inflammatory bowel disease. In dogs and rodents, treatment with RM-131 showed transient increased in GH levels that returned to baseline with continued administration [85].

The first clinical investigation of RM-131 was performed in women with type 2 diabetes and documentation of delayed GE and gastroparesis symptoms to assess pharmacodynamics and pharmacokinetic profiles, safety and tolerability of a single dose of RM-131. Results showed that compared with placebo, a single subcutaneous injection of RM-131 significantly increased GE $\mathrm{T}_{1 / 2}$ of solids. Improvements in in GE $\mathrm{T}_{\text {lag, }}$ GE $\mathrm{T}_{1 / 2}$ liquids, and colonic filling at 6 hours were observed, although not statistically significant. No significant effects was observed for total 
GCSI-DD score or composite scores for nausea, bloating postprandial fullness and pain; however, the study was not powered for these endpoints and baseline symptom severity was not a criterion for study eligibility [86].

A separate study of similar design conducted among patients with type 1 diabetes and prior documentation of delayed GE demonstrated that treatment with RM-131 resulted in significantly increased early phase GE with decreased gastric retention of solids at 1 hour ( $\mathrm{p}=$ 0.005 ) and 2 hours ( $\mathrm{p}=0.019)$; however no significant improvement in the primary end point, GE $T_{1 / 2}$ was observed, possibly due to the small sample size and relatively normal GE $T_{1 / 2}$ observed in a number of the patients at baseline. Unlike the previous study in patients with type 2 diabetes, symptom assessment showed significant reductions in total GCSI-DD and composite nausea, vomiting, fullness and pain scores for RM-131 when compared with placebo [87].

RM-131 was found to be safe and well tolerated in both trials, with no serious adverse events reported and no clinically significant impact on physical examination, ECG parameters, vital signs, or routine hematology and chemistry laboratory tests $[86,87]$. Although results of initial clinical trials with RM-131 have been promising, larger scale studies will be required to address generalizability and establish medium and long-term efficacy of this agent. Currently, phase 2 studies are underway among patients with type 1 and type 2 diabetes mellitus and gastroparesis to evaluate effects of multiple dosing regimens of RM-131 on gastric emptying and gastroparesis symptoms as well as overall safety and tolerability.

\section{Conclusion}


Modulation of ghrelin receptors with novel ghrelin agonists has been identified as a pathway for new therapeutic options for the treatment of GI motility disorders such as gastroparesis. Prokinetic effects of ghrelin on gastrointestinal motility have been demonstrated in through investigation of ghrelin in animal models and human studies of health and diseased states leading to clinical trials of several ghrelin receptor agonists in the treatment of gastroparesis. The intravenous macrocyclic peptidomimetic, TZP-101 showed initial promise; however, efficient acceleration of GE was not clearly shown [78] and a subsequent oral preparation of TZP-102 [81] was unable to demonstrate significant improvements in symptoms or GE over placebo and thus further study was stopped due to futility. Lack of efficacy of TZP102 has brought into question the utility of ghrelin receptor agonists as a useful treatment for gastroparesis [88]. However, termination of further investigation of ghrelin agonists would be premature as another agent, RM-131 demonstrated efficacy in small clinical trials of patients with diabetic gastroparesis with respect to GE endpoints and upper GI symptoms based on validated GE assessment by radioscintigraphy and patient-response outcomes by the gastrointestinal cardinal symptom index daily diary (GSCI-DD) [89]. These findings will require further validation in larger clinical trials to assess responses to multiple dosing regimens of longer duration in relevant patient populations.

Other points to consider with respect to development of ghrelin agonists are that clinical efficacy of these agents may be achieved through effects on alternative mechanisms aside from improvement in delayed GE that may be contributing to the pathogenesis of gastroparesis, particularly given the known lack of symptom correlation and GE [90]. Future studies of ghrelin agonists in the treatment of gastroparesis will also require assessment of effects on other gastric 
motor functions such as proximal gastric tone and gastric accommodation [69] which may accompany changes in GE. Efficacy in the treatment of gastroparesis may also be associated with the known antiemetic activity of ghrelin [91-93] and/or its effect on appetite and food intake [57,94]. Of note, "hunger” was reported more frequently among patients with type 1 diabetes with RM-131 administration [87]. In addition, responsiveness to treatment with ghrelin agonists among patients with gastroparesis may vary depending on the underlying etiology of the disease and further study among patients with post-surgical and idiopathic gastroparesis will need to be explored. Although actions of ghrelin appear to be mediated mainly through vagal signaling or directly via the enteric nervous system [19], extravagal effects of ghrelin on gastric motility have been show in patients with neurogenic causes of gastroparesis [75]. Furthermore, it has been suggested that there exists potential for desensitization of the ghrelin receptor with repeated dosing; however, in a study of co-administration of acylated and unacylated ghrelin no tachyphylaxis was observed with repeated administration in inducing decreased insulin concentrations [95].

In summary, ghrelin agonists remain an important area of ongoing clinical investigation in the treatment of gastroparesis. Potential therapeutic application of ghrelin and ghrelin agonists remain broad and its effects on gastric motility remain incompletely understood. Early clinical trials in small patient populations have shown promising results that will require further validation before widespread clinical use.

\section{Compliance with Ethics Guidelines}




\section{Conflict of Interest}

Andrea Shin has participated in past clinical research trials supported by Rhythm Pharmaceuticals

John M. Wo has performed clinical research trial supported by Tranzyme, Inc, GlaxoSmithKline, and Theravance.

\section{Human and Animal Rights and Informed Consent}

This article does not contain any studies with human or animal subjects performed by any of the authors.

Andrea Shin has been involved in two clinical trials involving human subjects (see references 86 and 87). Both trials were performed with approval by the Mayo Clinic Institutional Review Board after signed written informed consent and confirmation of patient study eligibility.

John M. Wo has been involved in clinical trials involving human subjects (see references 79, 80, 81 and 82). Trials were performed with approval by the University of Louisville Institutional Review Board after signed written informed consent and confirmation of patient study eligibility. 


\section{References}

Papers of particular interest, published recently, have been highlighted as:

* Of importance

* Ejskjaer N, Wo JM, Esfandyari T, Mazen Jamal M, Dimcevski G, Tarnow L et al. A phase 2a, randomized, double-blind 28-day study of TZP-102 a ghrelin receptor agonist for diabetic gastroparesis. Neurogastroenterol Motil. 2013;25:e140-50. doi: 10.1111/nmo.12064.

Phase 2a clinical trial of orally administered synthetic ghrelin-receptor agonist, TZP-102 shows improvement in gastroparesis symptoms among patients with diabetic gastroparesis, but is unable to display significant improvement in GE $T_{1 / 2}$.

* McCallum RW, Lembo A, Esfandyari T, Bhandari BR, Ejskjaer N, Cosentino C et al; TZP102 Phase 2b Study Group. Phase 2b, randomized, double-blind 12-week studies of TZP-102, a ghrelin receptor agonist for diabetic gastroparesis. Neurogastroenterol Motil. 2013;25:e705-717. doi: 10.1111/nmo.12184.

Phase $2 b$ clinical trial of ghrelin-receptor agonist, TZP-102, in patients with diabetic gastroparesis is unable to confirm prior results of significant improvement in gastroparesis symptoms and is again, unable to demonstrate significant improvement in gastric emptying. The trial is stopped due to futility.

* Van der Ploeg L, Laken H, Sharma S, Datta R, Halem H, Dong J et al. Preclinical gastrointestinal prokinetic efficacy and endocrine effects of the ghrelin mimetic RM-131. Life Sci. 2014;109:20-29.

Pentapeptide RM-131, a novel ghrelin receptor agonist, is studied in animal models to show enhancement of gastric emptying in rodent models of ileus, > 100-fold potency vs. human ghrelin, and transient increases in growth hormone that return to baseline with chronic administration.

* Shin A, Camilleri M, Busciglio I, Burton D, Stoner E, Noonan P et al. Randomized controlled phase Ib study of ghrelin agonist, RM-131, in type 2 diabetic women with delayed gastric emptying: pharmacokinetics and pharmacodynamics. Diabetes Care. 2013;36:41-48.

The first clinical trial of novel pentapeptide ghrelin-receptor agonist, RM-131, is performed in women in diabetic gastroparesis to show improvements in gastric emptying of solids.

* Shin A, Camilleri M, Busciglio I, Burton D, Smith SA, Vella A et al. The ghrelin agonist RM131 accelerates gastric emptying of solids and reduces symptoms in patients with type 1 diabetes mellitus. Clin Gastroenterol Hepatol. 2013;11:1453-1459.e4. doi: 10.1016/j.cgh.2013.04.019.

RM-131 in studied in a clinical trial of patients with type 1 diabetes and delayed gastric emptying. Results show acceleration of early phase gastric emptying and significant improvement in gastroparesis symptoms. 
1. Camilleri M, Bharucha AE, Farrugia G. Epidemiology, mechanisms, and management of diabetic gastroparesis. Clin Gastroenterol Hepatol. 2011;9:5-12.

2. Soykan I, Sivri B, Sarosiek I, Kiernan B, McCallum RW. Demography, clinical characteristics, psychological and abuse profiles, treatment, and long-term follow-up of patients with gastroparesis. Dig Dis Sci.1998;43:2398-2404.

3. Greydanus MP, Camilleri M, Colemont LJ, Phillips SF, Brown ML, Thomforde GM. Ileocolonic transfer of solid chyme in small intestinal neuropathies and myopathies. Gastroenterology. 1990;99:158-164.

4. Fraser RJ, Horowitz M, Maddox AF, Harding PE, Chatterton BE, Dent J. Hyperglycaemia slows gastric emptying in type 1 (insulin-dependent) diabetes mellitus. Diabetologia. 1990;33:675-680.

5. Grover M, Farrugia G, Lurken MS, Bernard CE, Faussone-Pellegrini MS, Smyrk TC et al. Cellular changes in diabetic and idiopathic gastroparesis. Gastroenterology. 2011;140:15751585, e1578.

6. He CL, Soffer EE, Ferris CD, Walsh RM, Szurszewski JH, Farrugia G. Loss of interstitial cells of Cajal and inhibitory innervation in insulin-dependent diabetes. Gastroenterology. 2001;121:427-434.

7. Choi KM, Gibbons SJ, Nguyen TV, Stoltz GJ, Lurken MS, Ordog T et al. Heme oxygenase-1 protects interstitial cells of Cajal from oxidative stress and reverses diabetic gastroparesis. Gastroenterology. 2008;135:2055-2064, e2051-2052.

8. Choi KM, Kashyap PC, Dutta N, Stoltz GJ, Ordog T, Shea Donohue T et al. CD206-positive M2 macrophages that express heme oxygenase-1 protect against diabetic gastroparesis in mice. Gastroenterology. 2010;138:2399-2409.e1

9. Watkins CC, Sawa A, Jaffrey S, Blackshaw S, Barrow RK, Snyder SH et al. Insulin restores neuronal nitric oxide synthase expression and function that is lost in diabetic gastropathy. J Clin Invest. 2000;106:373-384.

10. Spangeus A, El-Salhy M. Myenteric plexus of obese diabetic mice (an animal model of human type 2 diabetes). Histol Histopathol. 2001;16:159-165.

11. Hasler WL, Wilson LA, Parkman HP, Koch KL, Abell TL, Nguyen L et al. Factors related to abdominal pain in gastroparesis: contrast to patients with predominant nausea and vomiting. Neurogastroenterol Motil. 2013;25:427-38, e300-1. 
12. Nusrat S1, Bielefeldt K. Gastroparesis on the rise: incidence vs awareness? Neurogastroenterol Motil. 2013;25:16-22.

13. Camilleri M, Parkman HP, Shafi, MA, Abell TL, Gerson L. Clinical guideline: management of gastroparesis. Am J Gastroenterol. 2013 Jan;108:18-37.

14. http://www.fda.gov/newsevents/newsroom/pressannouncements/ucm149533.htm

15. Albibi R, McCallum RW. Metoclopramide: pharmacology and clinical application. Ann Intern Med. 1983;98:86-95.

16. Rao AS, Camilleri M. Review article: metoclopramide and tardive dyskinesia. Aliment Pharmacol Ther. 2010;31:11-9.

17. Oh JH, Pasricha PJ. Recent advances in the pathophysiology and treatment of gastroparesis. J Neurogastroenterol Motil. 2013;19:18-24.

18. Parkman HP, Mishra A, Jacobs M, Pathikonda M, Sachdeva P, Gaughan J, et al. Clinical response and side effects of metoclopramide: associations with clinical, demographic, and pharmacogenetic parameters. J Clin Gastroenterol. 2012;46:494-503.

19. Camilleri M, Papathanasopoulos A, Odunsi ST. Actions and therapeutic pathways of ghrelin for gastrointestinal disorders. Nat Rev Gastroenterol Hepatol. 2009;6:343-352.

20. Avau B, Carbone F, Tack J, Depoortere I. Ghrelin signaling in the gut, its physiological properties, and therapeutic potential. Neurogastroenterol Motil. 2013;25:720-32.

21. Kojima M, et al. Ghrelin is a growth-hormone-releasing acylated peptide from stomach. Nature. 1999;402:656-660.

22. Date $\mathrm{Y}, \mathrm{Kojima} \mathrm{M}$, Hosoda $\mathrm{H}$ et al. Ghrelin, a novel growth hormone- releasing acylated peptide, is synthesized in a distinct endocrine cell type in the gastrointestinal tracts of rats and humans. Endocrinology. 2000; 141: 4255-61.

23. Tomasetto C, Karam SM, Ribieras S, Masson R, Lefèbvre O, Staub A et al. Identification and characterization of a novel gastric peptide hormone: the motilin-related peptide. Gastroenterology. 2000;119:395-405.

24. Kanamoto N, Akamizu T, Tagami T, Hataya Y, Moriyama K, Takaya K et al. Genomic structure and characterization of the 5'-flanking region of the human ghrelin gene. Endocrinology. 2004;145:4144-4153

25. Zhang JV, Ren PG, Avsian-Kretchmer O, Luo CW, Rauch R, Klein C et al. Obestatin, a peptide encoded by the ghrelin gene, opposes ghrelin's effects on food intake. Science. 2005;310:996-999. 
26. Gardiner J, Bloom S. Ghrelin gets its GOAT. Cell Metab. 2008;7:193-194.

27. Yang J, Brown MS, Liang G, Grishin NV, Goldstein JL. Identification of the acyltransferase that octanoylates ghrelin, an appetite-stimulating peptide hormone. Cell. 2008;132:387-396.

28. Gnanapavan S, Kola B, Bustin SA, Morris DG, McGee P, Fairclough P et al. The tissue distribution of the mRNA of ghrelin and subtypes of its receptor, GHS-R, in humans. J Clin Endocrinol Metab. 2002;87:2988

29. Wren AM, Small CJ, Ward HL, Murphy KG, Dakin CL, Taheri S et al. The novel hypothalamic peptide ghrelin stimulates food intake and growth hormone secretion. Endocrinology. 2000;141:4325-4328.

30. van der Lely AJ, Tschöp M, Heiman ML, Ghigo E. Biological, physiological, pathophysiological, and pharmacological aspects of ghrelin. Endocr Rev. 2004;25:426-457.

31. Hattori N, Saito T, Yagyu T, Jiang BH, Kitagawa K, Inagaki C. GH, GH receptor, GH secretagogue receptor, and ghrelin expression in human T cells, B cells, and neutrophils. J Clin Endocrinol Metab. 2001;86:4284-4291.

32. Furuta M, Funabashi T, Kimura F. Intracerebroventricular administration of ghrelin rapidly suppresses pulsatile luteinizing hormone secretion in ovariectomized rats. Biochem Biophys Res Commun. 2001;288:780-785.

33. Nagaya N, Kojima M, Uematsu M, Yamagishi M, Hosoda H, Oya H et al. Hemodynamic and hormonal effects of human ghrelin in healthy volunteers. Am J Physiol Regul Integr Comp Physiol. 2001;280:R1483-R1487.

34. Wiley KE, Davenport AP. Comparison of vasodilators in human internal mammary artery: ghrelin is a potent physiological antagonist of endothelin-1. Br J Pharmacol. 2002;136:11461152 .

35. Kim SW, Her SJ, Park SJ, Kim D, Park KS, Lee HK et al. Ghrelin stimulates proliferation and differentiation and inhibits apoptosis in osteoblastic MC3T3-E1 cells. Bone. 2005;37:359369.

36. Theander-Carrillo C, Wiedmer P, Cettour-Rose P, Nogueiras R, Perez-Tilve D, Pfluger P et al. Ghrelin action in the brain controls adipocyte metabolism. J Clin Invest. 2006;116:19831993.

37. Nakazato M, Murakami N, Date Y, Kojima M, Matsuo H, Kangawa K et al. A role for ghrelin in the central regulation of feeding. Nature. 2001;409:194-198.

38. Malik S, McGlone F, Bedrossian D, Dagher A. Ghrelin modulates brain activity in areas that control appetitive behavior. Cell Metab. 2008; 7: 400-409. 
39. Asakawa A, Inui A, Kaga T, Katsuura G, Fujimiya M, Fujino MA et al. Antagonism of ghrelin receptor reduces food intake and body weight gain in mice. Gut. 2003;52:947-952.

40. Depoortere I. Targeting the ghrelin receptor to regulate food intake. Regul Pept. 2009;156:13-23.

41. Gil-Campos M, Canete R, Gil A. Hormones regulating lipid metabolism and plasma lipids in childhood obesity. Int J Obes Relat Metab Disord. 2004;28 (suppl 3):S75-S80.

42. Lundholm K, Gunnebo L, Körner U, Iresjö BM, Engström C, Hyltander A et al. Effects by daily long term provision of ghrelin to unselected weight-losing cancer patients: a randomized double-blind study. Cancer. 2010;116:2044-2052. doi: 10.1002/cncr.24917.

43. Henriques-Coelho T, Correia-Pinto J, Roncon-Albuquerque R Jr, Baptista MJ, Lourenço AP, Oliveira SM et al. Endogenous production of ghrelin and beneficial effects of its exogenous administration in monocrotaline-induced pulmonary hypertension. Am J Physiol Heart Circ Physiol. 2004;287:H2885-H2890.

44. Nagaya N, Moriya J, Yasumura Y, Uematsu M, Ono F, Shimizu W et al. Effects of ghrelin administration on left ventricular function, exercise capacity, and muscle wasting in patients with chronic heart failure. Circulation. 2004;110:3674-3679.

45. Dass NB, Munonyara M, Bassil AK, Hervieu GJ, Osbourne S, Corcoran S et al. Growth hormone secretagogue receptors in rat and human gastrointestinal tract and the effects of ghrelin. Neuroscience. 2003;120:443-453.

46. Xu L, Depoortere I, Tomasetto C, Zandecki M, Tang M, Timmermans JP et al. Evidence for the presence of motilin, ghrelin, and the motilin and ghrelin receptor in neurons of the myenteric plexus. Regul Pept. 2005;124:119-125.

47. Bassil AK, Dass NB, Sanger GJ. The prokinetic-like activity of ghrelin in rat isolated stomach is mediated via cholinergic and tachykininergic motor neurones. Eur J Pharmacol. 2006;544:146-152.

48. Kitazawa T, De Smet B, Verbeke K, Depoortere I, Peeters TL. Gastric motor effects of peptide and non-peptide ghrelin agonists in mice in vivo and in vitro. Gut. 2005;54:1078-1084.

49. Depoortere I, De Winter B, Thijs T, De Man J, Pelckmans P, Peeters T. Comparison of the gastroprokinetic effects of ghrelin, GHRP-6 and motilin in rats in vivo and in vitro. Eur J Pharmacol. 2005;515:160-168.

50. Qiu WC, Wang ZG, Wang WG, Yan J, Zheng Q. Gastric motor effects of ghrelin and growth hormone releasing peptide 6 in diabetic mice with gastroparesis. World J Gastroenterol. 2008;14:1419-1424. 
51. Nahata M, Saegusa Y, Sadakane C, Yamada C, Nakagawa K, Okubo N et al. Administration of exogenous acylated ghrelin or rikkunshito, an endogenous ghrelin enhancer, improves the decrease in postprandial gastric motility in an acute restraint stress mouse model. Neurogastroenterol Motil. 2014;26:821-831. doi: 10.1111/nmo.12336.

52. Miyano Y1, Sakata I, Kuroda K, Aizawa S, Tanaka T, Jogahara T et al. The role of the vagus nerve in the migrating motor complex and ghrelin- and motilin-induced gastric contraction in suncus. PLoS One. 2013;8:e64777. doi: 10.1371/journal.pone.0064777.

53. Fujino K, Inui A, Asakawa A, Kihara N, Fujimura M, Fujimiya M. Ghrelin induces fasted motor activity of the gastrointestinal tract in conscious fed rats. J Physiol. 2003;550:227-240.

54. Tanaka R, Inui A, Asakawa A, Atsuchi K, Ataka K, Fujimiya M. New method of manometric measurement of gastroduodenal motility in conscious mice: effects of ghrelin and Y2 depletion. Am J Physiol Gastrointest Liver Physiol. 2009;297:G1028-G1034.

55. Ariga H, Tsukamoto K, Chen C, Mantyh C, Pappas TN, Takahashi T. Endogenous acyl ghrelin is involved in mediating spontaneous phase III-like contractions of the rat stomach. Neurogastroenterol Motil. 2007;19:675-680.

56. Zheng J, Ariga H, Taniguchi H, Ludwig K, Takahashi T. Ghrelin regulates gastric phase IIIlike contractions in freely moving conscious mice. Neurogastroenterol Motil. 2009;21:78-84. doi: 10.1111/j.1365-2982.2008.01179.x.

57. Fujitsuka N, Asakawa A, Uezono Y, Minami K, Yamaguchi T, Niijima A et al. Potentiation of ghrelin signaling attenuates cancer anorexia-cachexia and prolongs survival. Transl Psychiatry. 2011;1:e23. doi: 10.1038/tp.2011.25.

58. Kitazawa T, Kaiya H, Taneike T. Contractile effects of ghrelin-related peptides on the chicken gastrointestinal tract in vitro. Peptides. 2007;28:617-624;

59. Kitazawa T, Nakamura T, Saeki A, Teraoka H, Hiraga T, Kaiya H. Molecular identification of ghrelin receptor (GHS-R1a) and its functional role in the gastrointestinal tract of the guineapig. Peptides. 2011;32:1876-1886.

60. Bassil AK, Dass NB, Murray CD, Muir A, Sanger GJ. Prokineticin-2, motilin, ghrelin and metoclopramide: prokinetic utility in mouse stomach and colon. Eur J Pharmacol. 2005;524:138-144.

61. De Smet B, Thijs T, Moechars D, Colsoul B, Polders L, Ver Donck L et al. Endogenous and exogenous ghrelin enhance the colonic and gastric manifestations of dextran sodium sulphateinduced colitis in mice. Neurogastroenterol Motil. 2009;21:59-70.

62. Olsson C, Holbrook JD, Bompadre G, Jönsson E, Hoyle CH, Sanger GJ et al. Identification of genes for the ghrelin and motilin receptors and a novel related gene in fish, and stimulation of 
intestinal motility in zebrafish (Danio rerio) by ghrelin and motilin. Gen Comp Endocrinol. 2008;155:217-226.

63. Trudel L, Tomasetto C, Rio MC, Bouin M, Plourde V, Eberling P et al. Ghrelin/motilinrelated peptide is a potent prokinetic to reverse gastric postoperative ileus in rat. Am J Physiol Gastrointest Liver Physiol. 2002;282:G948-G952..

64. Ohno T, Kamiyama Y, Aihara R, Nakabayashi T, Mochiki E, Asao T et al. Ghrelin does not stimulate gastrointestinal motility and gastric emptying: an experimental study of conscious dogs. Neurogastroenterol Motil. 2006;18:129-135.

65. Hirayama H, Shiina T, Shima T, Kuramoto H, Takewaki T, B Furness J et al. Contrasting effects of ghrelin and des-acyl ghrelin on the lumbo-sacral defecation center and regulation of colorectal motility in rats. Neurogastroenterol Motil. 2010;22:1124-1131. doi: 10.1111/j.13652982.2010.01553.x.

66. Tebbe JJ, Mronga S, Tebbe CG, Ortmann E, Arnold R, Schafer MK. Ghrelin-induced stimulation of colonic propulsion is dependent on hypothalamic neuropeptide Y1- and corticotrophin-releasing factor 1 receptor activation. J Neuroendocrinol. 2005;17:570-576.

67. Tebbe JJ, Tebbe CG, Mronga S, Ritter M, Schafer MK. Central neuropeptide Y receptors are involved in 3rd ventricular ghrelin induced alteration of colonic transit time in conscious fed rats. BMC Gastroenterol. 2005;5:5.

68. Tack J, Depoortere I, Bisschops R, Delporte C, Coulie B, Meulemans A et al Influence of ghrelin on interdigestive gastrointestinal motility in humans. Gut. 2006;55:327-333.

69. Ang D, Nicolai H, Vos R, Mimidis K, Akyuz F, Kindt S et al. Influence of ghrelin on the gastric accommodation reflex and on meal-induced satiety in man. Neurogastroenterol Motil. 2009;21:528-533.

70. Cremonini F, Camilleri M, Vazquez Roque M, McKinzie S, Burton D, Baxter K et al. Obesity does not increase effects of synthetic ghrelin on human gastric motor functions. Gastroenterology. 2006;131:1431-1439.

71. Levin F, Edholm T, Schmidt PT, Grybäck P, Jacobsson H, Degerblad M et al. Ghrelin stimulates gastric emptying and hunger in normal-weight humans. J Clin Endocrinol Metab. 2006;91:3296-3302.

72. Gaddipati KV, Simonian HP, Kresge KM, Boden GH, Parkman HP. Abnormal ghrelin and pancreatic polypeptide responses in gastroparesis. Dig Dis Sci. 2006;51:1339-1346.

73. Murray CD, Martin NM, Patterson M, Taylor SA, Ghatei MA, Kamm MA et al. Ghrelin enhances gastric emptying in diabetic gastroparesis: a double blind, placebo controlled, crossover study. Gut. 2005;54:1693-1698. 
74. Tack J, Depoortere I, Bisschops R, Verbeke K, Janssens J, Peeters T. Influence of ghrelin on gastric emptying and meal-related symptoms in idiopathic gastroparesis. Aliment Pharmacol Ther. 2005;22:847-853.

75. Binn M, Albert C, Gougeon A, Maerki H, Coulie B, Lemoyne M et al. Ghrelin gastrokinetic action in patients with neurogenic gastroparesis. Peptides. 2006;27:1603-1606.

76. Vestergaard ET, Hansen TK, Gormsen LC, Jakobsen P, Moller N, Christiansen JS et al. Constant intravenous ghrelin infusion in healthy young men: clinical pharmacokinetics and metabolic effects. Am J Physiol Endocrinol Metab. 2007;292:E1829-E1836.

77. Fraser G, HR H, Tannenbaum G. Pharmacological demarcation of the growth hormone, gut motility and feeding effects of ghrelin using a novel ghrelin receptor agonist. Endocrinol. 2008;149:620-628.

78. Ejskjaer N, Vestergaard ET, Hellström PM, Gormsen LC, Madsbad S, Madsen JL et al. Ghrelin agonist (TZP-101) accelerates gastric emptying in adults with diabetes and symptomatic gastroparesis: an exploratory, randomized, placebo-controlled, double-blind study. Aliment Pharm Ther. 2009;29:1179-1187.

79. Ejskjaer N, Dimcevski G, Wo JM, Hellström PM, Gormsen LC, Sarosiek I et al. Safety and efficacy of ghrelin agonist TZP-101 in relieving symptoms in patients with diabetic gastroparesis: a randomized, placebo-controlled study. Neurogastroenterol Motil. 2010;22:1069_ e281.

80. Wo JM, Ejskjaer N, Hellström PM, Malik RA, Pezzullo JC, Shaughnessy L et al. Randomised clinical trial: ghrelin agonist TZP-101 relieves gastroparesis associated with severe nausea and vomiting--randomised clinical study subset data. Aliment Pharmacol Ther. 2011;33:679-688.

81. Ejskjaer N, Wo JM, Esfandyari T, Mazen Jamal M, Dimcevski G, Tarnow L et al. A phase 2a, randomized, double-blind 28-day study of TZP-102 a ghrelin receptor agonist for diabetic gastroparesis. Neurogastroenterol Motil. 2013;25:e140-50. doi: 10.1111/nmo.12064.

82. McCallum RW, Lembo A, Esfandyari T, Bhandari BR, Ejskjaer N, Cosentino C et al; TZP102 Phase 2b Study Group. Phase 2b, randomized, double-blind 12-week studies of TZP-102, a ghrelin receptor agonist for diabetic gastroparesis. Neurogastroenterol Motil. 2013;25:e705-717. doi: $10.1111 / \mathrm{nmo.12184.}$

83. Camilleri M, Acosta A. A ghrelin agonist fails to show benefit in patients with diabetic gastroparesis: let's not throw the baby out with the bath water. Neurogastroenterol Motil. 2013;25:859-863. doi: 10.1111/nmo.12226. 
84. Van der Ploeg L, Laken H, Sharma S, Datta R, Halem H, Dong J et al. Preclinical gastrointestinal prokinetic efficacy and endocrine effects of the ghrelin mimetic RM-131. Life Sci. 2014;109:20-29.

85. Strassburg S, Anker SD, Castaneda TR, Burget L, Perez-Tilve D, Pfluger PT etal. Long-term effects of ghrelin and ghrelin receptor agonists on energy balance in rats. Am J Physiol Endocrinol Metab. 2008;295:E78-E84.

86. Shin A, Camilleri M, Busciglio I, Burton D, Stoner E, Noonan P et al. Randomized controlled phase Ib study of ghrelin agonist, RM-131, in type 2 diabetic women with delayed gastric emptying: pharmacokinetics and pharmacodynamics. Diabetes Care. 2013;36:41-48.

87. Shin A, Camilleri M, Busciglio I, Burton D, Smith SA, Vella A et al. The ghrelin agonist RM-131 accelerates gastric emptying of solids and reduces symptoms in patients with type 1 diabetes mellitus. Clin Gastroenterol Hepatol. 2013;11:1453-1459.e4. doi:

10.1016/j.cgh.2013.04.019.

88. Sanger GJ. Ghrelin and motilin receptor agonists: time to introduce bias into drug design. Neurogastroenterol Motil. 2014;26:149-155. doi: 10.1111/nmo.12300.

89. D.A. Revicki, M. Camilleri, B. Kuo, Norton NJ, Murray L, Palsgrove A et al. Development and content validity of a gastroparesis cardinal symptom index daily diary. Aliment Pharmacol Ther. 2009;30:670-680.

90. Talley NJ, Verlinden M, Jones M. Can symptoms discriminate among those with delayed or normal gastric emptying in dysmotility-like dyspepsia? Am J Gastroenterol. 2001;96:1422-1428.

91. Rudd JA, Ngan MP, Wai MK, King AG, Witherington J, Andrews PL et al. Anti-emetic activity of ghrelin in ferrets exposed to the cytotoxic anti-cancer agent cisplatin. Neurosci Lett. 2006;392:79-83.

92. Hejazi RA, Lavenbarg TH, McCallum RW. Elevated serum ghrelin levels in adult patients with cyclic vomiting syndrome. Am J Gastroenterol. 2011;106:1858-1859.

93. Oruç AS, Mert I, Akturk M, Aslan E, Polat B, Buyukkagnıcı U et al. Ghrelin and motilin levels in hyperemesis gravidarum. Arch Gynecol Obstet. 2013;287:1087-1092.

94. Hiura Y, Takiguchi S, Yamamoto K, Takahashi T, Kurokawa Y, Yamasaki M et al. Effects of ghrelin administration during chemotherapy with advanced esophageal cancer patients: a prospective, randomized, placebo-controlled phase 2 study. Cancer. 2012;118:4785-4794.

95. Kiewiet RM, van Aken MO, van der Weerd K, Uitterlinden P, Themmen AP, Hofland LJ et al. Effects of acute administration of acylated and unacylated ghrelin on glucose and insulin concentrations in morbidly obese subjects without overt diabetes. Eur J Endocrinol. 2009;161:567-573. 
Table 1: Recent clinical trials of synthetic ghrelin agonists in patients with diabetic gastroparesis

\begin{tabular}{|c|c|c|c|c|c|}
\hline Study & Intervention & Symptom Assessment & p-value & Gastric Emptying & p-value \\
\hline $\begin{array}{l}\text { Ejskjaer et } \\
\text { al. 2009 } \\
\text { [78] }\end{array}$ & TZP-101 & $\begin{array}{l}24 \% \text { decrease in PP } \\
\text { symptom intensity and } \\
37 \% \text { decrease in PP } \\
\text { fullness with TZP-101 }\end{array}$ & ns & $\begin{array}{l}20 \% \text { reduction in } \\
\text { solid GE T } 1 / 2 \text { with } \\
\text { TZP-101 vs. pcbo }\end{array}$ & 0.043 \\
\hline $\begin{array}{l}\text { Ejskjaer et } \\
\text { al. 2010 } \\
\text { [79] }\end{array}$ & TZP-101 & $\begin{array}{l}\text { Mean change from } \\
\text { baseline in GCSI loss of } \\
\text { appetite (-2.5 TZP-101, } \\
-1.6 \text { pcbo) and } \\
\text { vomiting ( }-2.2 \text { TZP- } \\
101,-1.0 \text { pcbo) at day } 4 \\
\text { (secondary endpoint) }\end{array}$ & $\begin{array}{l}\mathrm{p}=0.034 \\
\mathrm{p}=0.006\end{array}$ & $\begin{array}{l}25 \% \text { change in } \\
\text { GE T } \text { T/2 with } \\
\text { TZP-101 (subset) } \\
\text { vs. 8\% } \\
\text { improvement } \\
\text { with pcbo }\end{array}$ & ns \\
\hline $\begin{array}{l}\text { Wo et al. } \\
2011 \text { [80] }\end{array}$ & $\begin{array}{l}\text { TZP-101 (80 } \\
\mu / \mathrm{kg})\end{array}$ & $\begin{array}{l}\text { Change in mean GCSI } \\
\text { Nausea/Vomiting and } \\
\text { Vomiting at day } 4 \\
\text { reduced with TZP-101 } \\
\text { vs. pcbo }\end{array}$ & $\begin{array}{l}\mathrm{p}<0.001 ; \\
\mathrm{p}=0.008\end{array}$ & NA & NA \\
\hline $\begin{array}{l}\text { Ejskjaer et } \\
\text { al. } 2013 \\
\text { [81] }\end{array}$ & TZP-102 & $\begin{array}{l}\text { Improvement in mean } \\
\text { GSCI total score (-1.2 } \\
\text { with TZP-102; }-0.6 \\
\text { with pcbo) }\end{array}$ & $\mathrm{p}=0.02$ & $\begin{array}{l}\text { No difference in } \\
\text { GE } T_{1 / 2} \text { for TZP- } \\
102 \text { vs. pcbo }\end{array}$ & ns \\
\hline $\begin{array}{l}\text { McCallum } \\
\text { et al. } 2013 \\
\text { [82] }\end{array}$ & TZP-102 & $\begin{array}{l}\text { Improvement in GSDD } \\
\text { seen in all treatment } \\
\text { arms }\end{array}$ & ns & $\begin{array}{l}\text { No significant } \\
\text { difference in } \\
\text { change from } \\
\text { baseline with } \\
\text { TZP-102 or pcbo }\end{array}$ & ns \\
\hline $\begin{array}{l}\text { Shin et al. } \\
2013 \text { [86] }\end{array}$ & RM-131 & $\begin{array}{l}\text { No significant effects } \\
\text { for total GCSI-DD } \\
\text { score or composite } \\
\text { scores }\end{array}$ & ns & 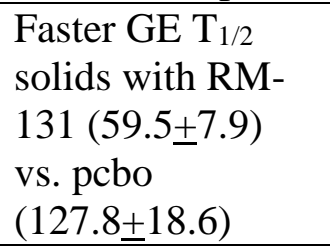 & 0.011 \\
\hline $\begin{array}{l}\text { Shin et al. } \\
2013 \text { [87] }\end{array}$ & RM-131 & $\begin{array}{l}\text { Total GCSI-DD score } \\
0.17 \text { on RM-131 and } \\
0.79 \text { on pcbo; lower } \\
\text { NVFP composite scores } \\
\text { with RM-131 }\end{array}$ & $\begin{array}{l}\mathrm{p}=0.041 ; \\
\mathrm{p}=0.041\end{array}$ & $\begin{array}{l}\text { Faster GE solids } \\
\text { at } 1 \text { and } 2 \text { h with } \\
\text { RM-131 vs. pcbo. }\end{array}$ & $\begin{array}{l}\mathrm{p}=0.005 \\
\mathrm{p}=0.019\end{array}$ \\
\hline
\end{tabular}

PP=postprandial; pcbo=placebo; GCSI=Gastroparesis Cardinal Symptom Index; GSDD=Daily Diary of Gastroparesis Symptoms Questionnaire; NVFP=nausea, vomiting, fullness, pain 


\section{Figure Legend}

Figure 1: Change in mean Nausea/Vomiting subscale scores (a) and Vomiting scores (b) over time. The slopes for days 1-4 in (a) are significantly different for the $80 \mu \mathrm{g} / \mathrm{kg}$ group vs. placebo $(P<0.001)$ and All TZP-101 vs. placebo $(P=0.004)$, and in (b) for $80 \mu \mathrm{g} / \mathrm{kg}$ group vs. placebo $(P=0.008)$ and All TZP-101 vs. placebo $(P=0.005)$. 


\section{Figure 1}

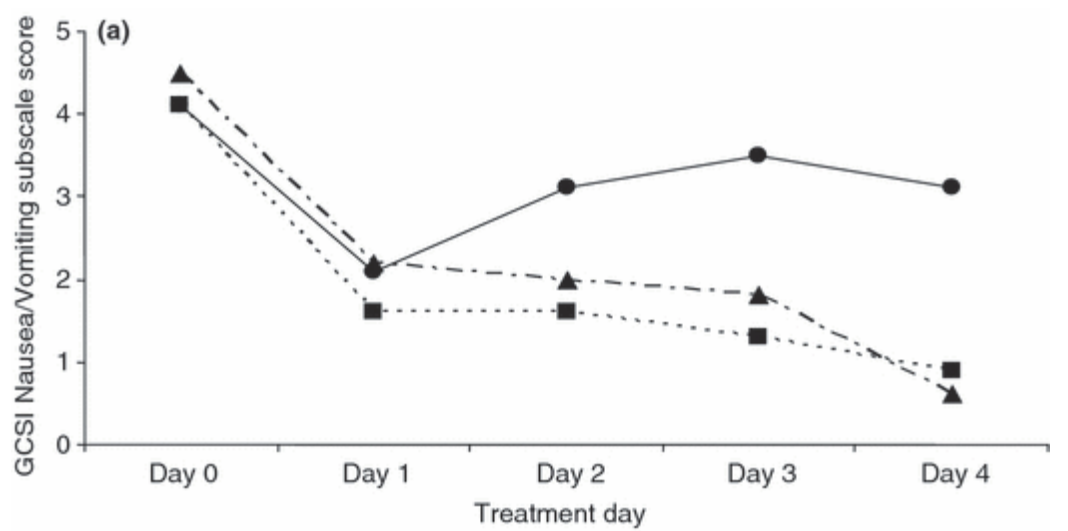

(b)

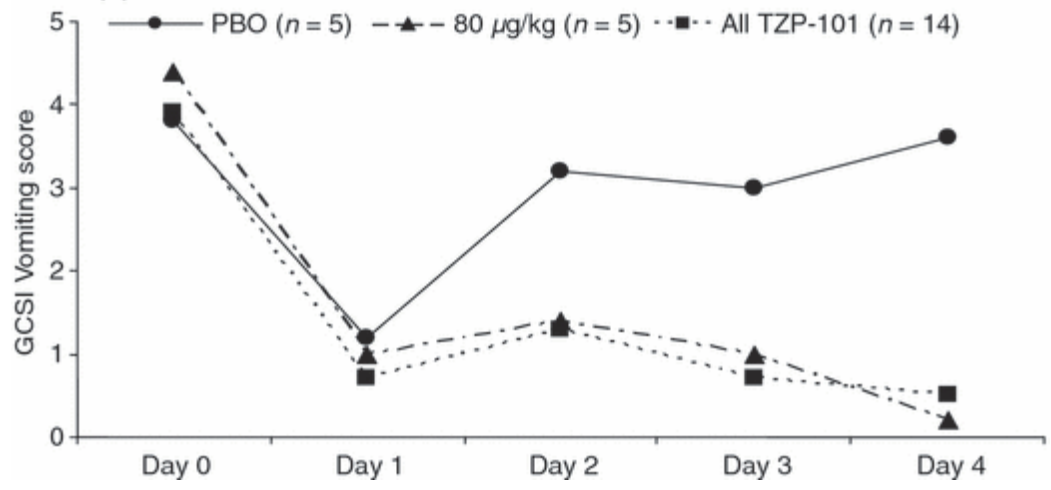

Page 26 